\title{
Face Politics
}

\author{
Jenny Edkins
}

New York: Routledge, 2015. 230 pages.

Over the last decade, public discourse in Europe and North America has been overwhelmingly in favor of banning the face veil (niqab). Politicians like Jack Straw in the UK or John Charest in Québec have commented on its putative hindrance to community integration due to its covering of the face. So a book entitled Face Politics would seem to offer some insights into this anti-niqab dynamic. A quick perusal of the index for "niqab," "Islam," and "Muslim women," however, comes up unexpectedly empty. What, then, is "face politics" 
and how can an academic discussion about the "face" not mention niqab, arguably one of the most burning issues of "face politics" this century?

The book is a profound, intellectually challenging, sometimes dense, and yet empathetic and beautifully written exploration of how contemporary western politics is predicated around individuality and the separatedness of being, signified by the idea of the face as a "window onto the [individual's] soul" (p. 165). Because she believes that "a politics that makes the face is a politics that produces the person as an object" (p.7), the author wishes to propose a different concept of the face, that of a mask hiding our inseparable connectedness, and concludes that such an alternative would lead to a profoundly different, and better, political society, one symbolized by the concept of the tango. Indeed, the tagline on the dedication page is "If the face is a politics, dismantling the face is also a politics," from French philosopher Gilles Deleuze and psychoanalyst Félix Guattari's 1980 book A Thousand Plateaus: Capitalism and Schizophrenia.

In the preface, Edkins explains how she came to write this book, which began as a far simpler "project on the contemporary politics of the portrait photograph in the west" (p. xv). She was intrigued by the posters of people missing after 9/11 that were posted around New York and the artist Sebastião Saldago's 2003 exhibition of images of refugee children in camps. She wanted to know what "portrait photographs do. Why are they so powerful in the western imaginary? Why are they used so often? What response do they prompt, what political action? (p. xv)." Her interest in the New York posters spun off into an inquiry about missing persons more generally, and the current book grew out of a shift from an interest in images of the face to a "more substantive exploration of face politics" (p. xv). Questions about portraits and photographs of faces, about the impact of "digital photography, moving images, smart phones, Facebook pages" on portraiture led Edkins to ask questions like:

Aren't new media artists now exploring altered ways of making faces generic faces, reconstructed faces - or even obliterating the face? Does this go alongside a new concept of the person, and new political possibilities? ...What is the face in the photograph? Why the face or headshot? Why obliterate the face? What is the face anyway?" (p. xvi).

To answer these questions, Edkins, a scholar of international relations, delves into neuroscience, psychology, anthropology, visual studies, and art theory. Along the way she explores philosophical concepts such as the nature of being, what makes a person or an individual, and how the face relates to indi- 
viduality and becomes a basis for political society. The beauty of the book is her accessible writing style, empathy with the reader as well as the subjects whose portraits, photographs, and/or selves she writes about, and honest selfdisclosure about her own reactions to "the face." Face Politics is not jargonistic; however, due to the depth of its philosophical enquiry, its argument is sometimes complex.

Edkins begins by noting the face "is paradoxical" (p.1):

We pay attention to reading each other's faces - reading people's moods, personalities and origins into their facial appearance. We search for clues as to who the persons opposite us may be and what they may be thinking ... On the other hand, the importance of the face ... is often traced to a particular historical and geographical juncture. In the European imagination, the face came to prominence in painting with the beginnings of portraiture in the Renaissance and Enlightenment periods ... historians of art have drawn a connection between the rise and spread of portraiture and the rise of the concept of the individual - or rather, at least at first, the individual propertied male as the building block of European political organisation. (pp. 1-2)

Face Politics includes an Introduction and four chapters, with the last part of chapter 4 serving as a summing up and conclusion. In chapter 1, "Faces in Photographs," Edkins explores what happens when we look at photographs of faces using several artistic exhibitions, including Suzanne Opton's Soldier face (photographs of returned American soldiers with their heads lying vertically on a table and displayed controversially on billboards); Robert Lyon's Intimate Enemy (a book with photographs of perpetrators and victims in Rwanda's genocide; without captions saying which photograph is of which kind of person); and Ly Daravuth's Messengers (a 2000 exhibition in Phnom Penh), mixing up (without saying who is who) photographs of children who used to be messengers for the Khmer Rouge with contemporary children dressed as messengers. All of this is designed to destabilize the idea that we can "read character, experience, or emotion" (p. 8) from the face.

Chapter 2, "Moving Faces," takes us into neuroscience, including what happens to people who have paralyzed faces that cannot show emotion (Möbius Syndrome), exploring scientific evidence as to whether or not we can read emotion from facial expression, the science around people's ability to mirror facial emotional expressions, and artistic work exploring a connection between humans and inanimate objects. Chapter 3, "From Face Capture to Face Blindness," begins with the growing phenomenon of face-capture software and its 
implications for political control, and then moves into a discussion of scientific and artistic work on the overstated ability of computer software and people to recognize faces and physiognomy. It ends with a discussion of the science of face blindness, those people who struggle or cannot recognize even family faces. Finally, chapter 4, "Facelessness: Another Politics?" opens with a study of facial disfigurement, its impact on the person and those around them, and scientific and artistic attempts to help people cope through plastic surgery (i.e., artists painting portraits of the process of the plastic surgery). After analyzing the experience, science, and art around face transplants, the chapter's final section, "Face, Personhood, and Politics," concludes the entire book.

There is obviously much to respond to in such a multifaceted and wideranging book. Let me finish by returning to what prompted my interest in the book in the first place: face politics and the niqab. By using the word burka on one page, nestled in between her discussion of facial disfiguration and face transplants, Edkins does refer to the face politics of Muslimah face coverings. Presenting the burka as somehow related to how cosmetic surgery reveals the face to be a mask, the burka's apparent facelessness produces the trauma of not being able to see the mask (face) of a person, which is normally what we rely on to conceal "the awful way in which we are all ultimately unfathomable to each other." (p. 159). The burka thus "exposes our fear of our own precarious subjecthood" (p. 160).

To give such short shrift to one of western society's most pressing questions is surprising. In other chapters the author deals extensively with statements made by people suffering from Möbius Syndrome, face blindness, facial disfigurement, face transplants, and so on. So why not discuss the experiences of those who wear the niqab? To be fair, she does state clearly that this book is meant only as an introduction to what is obviously an immense topic requiring further research (p. xvii). Yet to place her brief discussion of the burka in a section on facelessness demonstrates that she herself is still writing about the "face" from inside a western paradigm, even as she tries to envisage a politics of the face that is about empathy and connectedness as opposed to separation.

Niqabis can experience facelessness in western society, including among fellow Muslims attuned to western concepts of the face, akin to how others react to facial disfigurement (p. 148), but not among a Muslim community attuned to the normality, even meritoriousness, of covering the face. We can learn to interact with a niqabi on a level that does not require access to the face. We can even learn to recognize her, read emotion from her, and feel connected to her. 
An alternate politics of the face need not see a face covering as "exposing precarious subjecthood," but rather as encouraging connectedness through nonfacial means. Of course the authoritarian nature of many contemporary Muslim-majority societies and political movements seeking to impose this practice raises questions about what kind of politics face covering can lead to, and whether more progressive alternatives are also possible, as Edkins has asked in Face Politics. There are evidently rich possibilities in using her work for questions related to Muslim women and face politics in Muslim-majority and western societies.

Kathy Bullock

Director of Research, The Tessellate Institute Lecturer, University of Toronto, Mississauga, ON, Canada 